\title{
Hubungan Antara Asupan Zat Gizi Makro dan Status Gizi dengan Kebugaran Jasmani Mahasiswa UKM Taekwondo
}

\section{Relationship between Macronutrient Intake, Nutritional Status and Physical Fitness among College Students in Student's Taekwondo Club}

\author{
Intan Galih Cornia*1, Merryana Adriani ${ }^{1}$
}

\begin{abstract}
ABSTRAK
Latar Belakang: Taekwondo merupakan aktivitas fisik atau gerakan anggota tubuh yang dilakukan secara berulang dan organ yang paling aktif yaitu otot. Permasalah yang sering terjadi pada olahragawan yaitu suka konsumsi makanan yang tidak teratur sehingga asupan gizinya kurang tercukupi. Asupan gizi yang baik diperoleh dari asupan gizi yang cukup sehingga kebugaran jasmaninya baik.

Tujuan: Tujuan dari penelitian ini adalah menganalisis hubungan antara asupan zat gizi makro dan status gizi dengan kebugaran jasmani mahasiswa UKM taekwondo.

Metode: Penelitian ini menggunakan desain studi cross sectional dengan jumlah sampel 52 orang, diambil secara acak sederhana menggunakan simple random sampling. Pengumpulan data meliputi status gizi dengan cara penimbangan berat dan pengukuran tinggi badan untuk mengetahui Indeks Massa Tubuh (IMT), food recall $2 \times 24$ untuk mengetahui asupan makannya dan tes balke untuk kebugaran jasmani. Analisis data yang digunakan dalam penelitian ini adalah analisis univariat dan bivariat dengan menggunakan kolerasi pearson.

Hasil: Hasil penelitian menunjukkan terdapat hubungan antara status gizi $(p=0,014)$ dengan kebugaran jasmani sedangkan asupan energi, protein, karbohidrat dan lemak $(P=0,05)$ tidak terdapat hubungan dengan kebugaran jasmani.

Kesimpulan: Status gizi berhubungan dengan kebugaran jasmani. Responden yang memiliki status gizi normal cenderung memiliki kebugaran jasmani yang baik. Perlu dilakukan penambahan informasi terkait zat gizi agar tercipta status gizi yang baik.
\end{abstract}

Kata Kunci: asupan makan, status gizi, kebugaran jasmani, taekwondo 


\section{ABSTRACT}

Background: Taekwondo is a physical activity or body movement that is conducted repeatedly with muscles as the most active organ. The problems that occurs to the athletes is the poor-organized consumption pattern, thus they lack of nutritional intake. The good nutritional intake is obtained from the sufficient nutritional intake so that the physical fitness becomes better. Meanwhile, young adults require sufficient nutritional intake so that their physical fitness can be better.

Objective: This research aimed to analyze the relationship between the nutritional intake and nutrition status with the physical fitness of the university students joining the student activity unit of taekwondo in Universitas Airlangga Surabaya.

Methods: This research was the analytical research with the cross-sectional design. The sample of the research was as many as 52 people who were acquired by utilizing the simple random sampling. The data collection included nutritional status by measuring the weight and height to figure out the Body Mass Index (BMI) and $2 \times 24$ hours food recall to understand the food intake.

Results: The result demonstrated that there was a relationship between the nutritional status $(p=0.014)$ and the intake of energy, protein, carbohydrate, and fat $(p=0.05)$ had no relationship with the physical fitness.

Conclusions: It could that the nutritional status was related to the physical fitness. The respondents who had normal nutrition status obtained the good physical fitness. There should be the addition of information regarding the nutrients to obtain the good nutritional status.

Keywords: nutrition intake, nutrition status, physical fitness, taekwondo

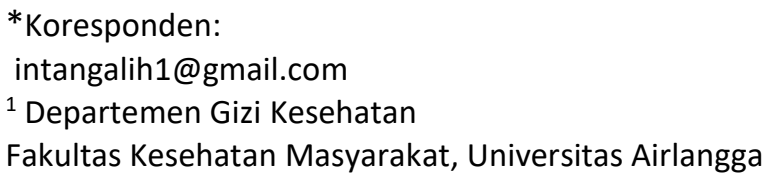

\section{PENDAHULUAN}

Olahraga merupakan aktivitas fisik yang dilakukan secara berulang-ulang dan organ yang aktif yaitu otot. Otot memberikan pengaruh langsung ataupun tidak langsung yang dapat meningkatkan taraf kesehatan dan kebugaran ${ }^{1}$. Dunia olahraga dikenal oleh masyarakat dengan berbagai macam cabang olahraga seperti olahraga beladiri yaitu kempo, karate, tapak suci, jujitsu, perisai diri, merpati putih, Persaudaraan Setia Hati Terate (PSHT). Berdasarkan hasil observasi di kota Surabaya terdapat banyak Universitas negeri dan swasta salah satunya di Universitas Airlangga surabaya yang terdapat Unit Kegiatan Mahasiswa (UKM) misalnya UKM sepak bola, UKM basket dan UKM taekwondo. Jadwal latihan UKM taekwondo dilaksanakan pada waktu satu minggu tiga kali. Meskipun organisasi UKM merupakan seorang mahasiswa, namun kegiatan UKM juga

mempersilahkan bagi umum untuk bergabung menjadi bagian dari UKM.

Ciri utama olahraga taekowondo yaitu melibatkan pertahanan fisik dan serangan teknik melawan saingan dengan menggunakan kaki telanjang dan tangan ${ }^{2}$. Fisik yang bugar diperoleh dari asupan yang sesuai dengan kebutuhan tubuh sehingga, olahragawan membutuhkan asupan makan yang baik yaitu asupan makan yang didalamnya mengandung sumber energi, protein, karbohidrat, lemak, vitamin dan mineral yang diperlukan untuk pertumbuhan dan pemeliharaan tubuh ${ }^{3}$. Pada umumnya status gizi seseorang dipengaruhi oleh asupan tubuh yang memperoleh cukup zat gizi secara efisien sehingga mempengaruhi pertumbuhan fisiknya.

Remaja akhir berdasarkan Depkes RI yaitu 17-25 tahun ${ }^{4}$. Oleh karena itu perlu asupan makan yang baik pada remaja yang mengandung jumlah zat gizi yang lebih tinggi daripada sebelumnya. Kebiasaan seorang olahragawan dapat dipengaruhi oleh 
kehidupan sosial dan aktivitas yang tinggi. Kebiasan makan yang belum baik berasal dari kebiasaan makan keluarga yang sudah tertanam sejak kecil akan terus terjadi pada usia remaja ${ }^{5}$. Kebiasaan mengkonsumsi makanan yang melebihi kecukupan zat gizi juga dapat menimbulkan masalah gizi lebih. Gaya hidup seseorang dapat mempengaruhi pola makan, aktifitas fisik serta status gizi ${ }^{6}$. Kebutuhan gizi ditentukan dari kebutuhan basal, keadaan fisiologis, keadaan sakit, gizi kurang dan gizi lebih?

Semakin beragam pola makanan yang dikonsumsi semakin mudah terpenuhi kebutuhan akan berbagai zat gizi ${ }^{8}$. Olahragawan membutuhkan semua zat gizi yaitu karbohidrat, lemak, protein, vitamin, mineral dan air agar dapat hidup dan beraktivitas sehari. Makanan yang dikonsumsi harus mengandung zat gizi dalam jumlah dan mutu yang cukup sesuai dengan yang dibutuhkan oleh tubuh. Widyakarya Nasional Pangan dan Gizi VI (WKNPG) tahun 2012, menganjurkan Angka Kecukupan Gizi (AKG) energi untuk remaja perempuan yaitu 2.0002.200 kkal dan remaja laki-laki antara 2.4002.800 kkal setiap hari.

Data diatas melatar belakangi penelitian tentang hubungan antara asupan zat gizi makro dan status gizi dengan kebugaran jasmani mahasiswa UKM taekwondo.

\section{METODE}

Penelitian ini merupakan jenis penelitian observasional analitik dengan desain studi cross sectional. Sampel dalam penelitian ini adalah 52 mahasiswa UKM taekwondo yang didapatkan melalui perhitungan rumus didapatkan sampel sebanyak 52 orang kriteria inklusi yaitu olahragawan dengan sabuk putih dan kuning hal ini dikarenakan kedua sabuk memiliki jam bertanding yang cukup sedangkan pada sabuk akhir sudah diangap sebagai pelatih ${ }^{9}$. Pengambilan sampel dalam penelitian ini menggunakan metode simple random sampling mahasiswa UKM taekwondo di Universitas Airlangga Surabaya.

Karakteristik mahasiswa dalam penelitian ini meliputi umur dan jenis kelamin. Data asupan makan diperoleh melalui wawancara dengan menggunakan kuesioner food recall $2 \times 24$ hours, status gizi diperoleh melalui pengukuran berat dan tinggi badan untuk mengetahui Indeks Massa Tubuh (IMT) responden. Kebugaran jasmani diperoleh melalui test balke dengan jalan atau lari secepat mungkin selama 15 menit $^{10}$.

Hasil pengukuran pada berat badan mahasiswa menggunakan timbangan digital (seca) dengan ketelitian 0,1 kg dan pengukuran tinggi badan dengan ketelitian 0,1 $\mathrm{cm}$. Food recall $2 \times 24$ jam dilakukan pada dua hari dan tidak berurutan untuk mengetahui asupan energi, protein, karbohidrat dan lemak kemudian asupan makan dibandingkan dengan AKG berdasarkan usia 19-29 tahun dengan kategori kurang $<77 \%$ AKG dan cukup $\geq 77 \% \mathrm{AKG}^{11}$. Tes balke dilakukan dengan tes jalan atau lari secepat mungkin dalam waktu 15 menit dan dihitung menggunakan rumus $\mathrm{VO}_{2}$ max dalam meter dengan kategori baik sekali, baik, sedang, kurang dan kurang sekali. Hasil dari penelitian ini dianalisis menggunakan analisis univariat dan bivariat dengan menggunakan kolerasi pearson. Penelitian lulus etik oleh Komisi Etik Fakultas Kesehatan Masyarakat Universitas Airlangga Surabaya dengan sertifikat etik no 341-KEPK.

\section{HASIL DAN PEMBAHASAN}

Berdasarkan hasil penelitian diketahui Karakteristik jenis kelamin pada mahasiswa UKM taekwondo Universitas Airlangga yang ditampilkan pada tabel 1 menunjukkan bahwa mahasiswa laki-laki sebanyak $46,2 \%$ dan perempuan sebanyak $53,8 \%$.

Tabel 1. Distribusi Karakteristik Mahasiswa UKM Taekwondo di Universitas Airlangga Surabaya Tahun 2017

\begin{tabular}{lcc}
\hline Karakteristik & $\mathbf{n}$ & $\mathbf{\%}$ \\
\hline $\begin{array}{l}\text { Jenis Kelamin Balita } \\
\text { Laki-laki }\end{array}$ & 24 & 46,2 \\
$\quad$ Perempuan & 28 & 53,8 \\
\hline Total & 52 & 100,0 \\
\hline Umur & & \\
19 tahun & 7 & 13,5 \\
20 tahun & 21 & 40,4 \\
21 tahun & 19 & 36,5 \\
22 tahun & 5 & 9,6 \\
\hline Total & 52 & 100,0 \\
\hline
\end{tabular}


Responden dalam penelitian ini memiliki umur 19 tahun hingga 22 tahun. Pada kelompok umur responden terbanyak yaitu umur 20 tahun sebanyak 40,4\%.

Pada tabel 2 menunjukkan bahwa asupan energi yang cukup cenderung memiliki kebugaran jasmani baik sebanyak $50 \%$, asupan protein yang cukup cenderung memiliki kebugaran jasmani baik yaitu $42,4 \%$, asupan karbohidrat yang cukup cenderung memiliki kebugaran jamani sedang sebanyak $75 \%$ dan asupan lemak yang cukup cenderung memiliki kebugaran jasmani sedang sebanyak $57,1 \%$.

Berdasarkan penelitian menunjukkan bahwa tidak terdapat hubungan asupan energi dengan kebugaran jasmani. Hasil ini ditunjang untuk penelitian lain yang menyebutkan bahwa tidak terdapat hubungan tingkat konsumsi energi dengan kesegaran jasmani pada posisi tosser dan smasher atlet bola voli $^{12}$. Energi merupakan salah satu hasil metabolisme karbohidrat, protein dan lemak. Berfungsi sebagai zat tenaga untuk metabolisme pertumbuhan, pengaturan suhu dan kegiatan fisik. Sumber energi yang terdapat dalam bahan makanan adalah karbohidrat, lemak dan protein. Satu gram karbohidrat menghasilkan empat kalori.

Tabel 2. Hasil Tabulasi Silang Asupan Makan Mahasiswa UKM Taekwondo di Universitas Airlangga Surabaya Tahun 2017

\begin{tabular}{|c|c|c|c|c|c|c|c|c|c|c|c|c|}
\hline \multirow{3}{*}{$\begin{array}{ll}\text { Asupan } & \\
\text { Zat } & \text { Gizi } \\
\text { Makro } & \end{array}$} & \multicolumn{8}{|c|}{ Kebugaran Jasmani } & \multirow{2}{*}{\multicolumn{2}{|c|}{ Total }} & \multirow{3}{*}{ nilai $p$} & \multirow{3}{*}{ nilai $r$} \\
\hline & \multicolumn{2}{|c|}{ Baik Sekali } & \multicolumn{2}{|c|}{ Baik } & \multicolumn{2}{|c|}{ Sedang } & \multicolumn{2}{|c|}{ Kurang } & & & & \\
\hline & $\mathbf{n}$ & $\%$ & $n$ & $\%$ & $n$ & $\%$ & $\mathbf{n}$ & $\%$ & $\mathbf{N}$ & $\%$ & & \\
\hline \multicolumn{13}{|l|}{ Asupan } \\
\hline \multicolumn{13}{|l|}{ Energi } \\
\hline Kurang & 3 & 6,3 & 19 & 39,6 & 19 & 39,6 & 7 & 14,2 & 48 & 100,0 & 0,721 & $-0,051$ \\
\hline Cukup & 0 & 0,0 & 2 & 50,0 & 2 & 50,0 & 0 & 0,0 & 4 & 100,0 & & \\
\hline \multicolumn{13}{|l|}{ Asupan } \\
\hline \multicolumn{13}{|l|}{ Protein } \\
\hline Kurang & 0 & 0,0 & 7 & 36,8 & 9 & 47,4 & 3 & 15,8 & 19 & 100,0 & 0,334 & 0,137 \\
\hline Cukup & 3 & 9,1 & 14 & 42,4 & 12 & 36,4 & 4 & 12,1 & 33 & 100,0 & & \\
\hline \multicolumn{13}{|l|}{ Asupan } \\
\hline \multicolumn{13}{|l|}{ Karbohidrat } \\
\hline Kurang & 3 & 6,3 & 20 & 41,7 & 18 & 37,5 & 7 & 14,5 & 48 & 100,0 & 0,707 & $-0,053$ \\
\hline Cukup & 0 & 0,0 & 1 & 25,0 & 3 & 75,0 & 0 & 0,0 & 4 & 100,0 & & \\
\hline \multicolumn{13}{|l|}{ Asupan } \\
\hline \multicolumn{13}{|l|}{ Lemak } \\
\hline Kurang & 3 & 6,7 & 18 & 40,0 & 17 & 37,8 & 7 & 15,1 & 45 & 100,0 & 0,147 & 0,204 \\
\hline Cukup & 0 & 0,0 & 3 & 42,9 & 4 & 57,1 & 0 & 0,0 & 7 & 100,0 & & \\
\hline
\end{tabular}

Tabel 3. Hasil Tabulasi Silang Status Gizi Dengan Kebugaran Jasmani Pada Mahasiswa UKM Taekwondo di Universitas Airlangga Surabaya Tahun 2017

\begin{tabular}{|c|c|c|c|c|c|c|c|c|c|c|}
\hline \multirow{3}{*}{ Status Gizi } & \multicolumn{8}{|c|}{ Kebugaran Jasmani } & \multirow{2}{*}{\multicolumn{2}{|c|}{ Total }} \\
\hline & \multicolumn{2}{|c|}{ Baik Sekali } & \multicolumn{2}{|c|}{ Baik } & \multicolumn{2}{|c|}{ Sedang } & \multicolumn{2}{|c|}{ Kurang } & & \\
\hline & $\mathrm{n}$ & $\%$ & $\mathbf{n}$ & $\%$ & $n$ & $\%$ & $\mathrm{n}$ & $\%$ & $\mathbf{n}$ & $\%$ \\
\hline Kurus & 2 & 15,4 & 2 & 15,4 & 6 & 46,2 & 3 & 23 & 13 & 100,0 \\
\hline Normal & 1 & 2,9 & 16 & 45,7 & 15 & 42,9 & 3 & 8,5 & 35 & 100,0 \\
\hline Gemuk & 0 & 0,0 & 1 & 50,0 & 0 & 0,0 & 1 & 50,0 & 2 & 100,0 \\
\hline Obesitas & 0 & 0,0 & 2 & 100,0 & 0 & 0,0 & 0 & 0,0 & 2 & 100,0 \\
\hline Total & 3 & 5,8 & 21 & 40,4 & 21 & 40,4 & 7 & 13,4 & 52 & 100,0 \\
\hline \multicolumn{11}{|l|}{$p=0,014$} \\
\hline$r=0,340$ & & & & & & & & & & \\
\hline
\end{tabular}


Berdasarkan hasil penelitian tidak terdapat hubungan asupan protein dengan kebugaran jasmani. Penelitian lain juga menyebutkan bahwa tidak terdapat hubungan asupan protein dengan kesegaran jasmani pada anggota klub tenis meja satelit dan salero star kota Ternate ${ }^{13}$. Protein terdiri dari asam-asam amino. Selain menyediakan asam amino esensial, protein juga menyuplai energi dalam keadaan energi terbatas dari karbohidrat dan lemak. Terdapat berbagai fungsi protein di dalam tubuh antara lain kekebalan tubuh, pengganti jaringan yang rusak dan untuk pertumbuhan. Protein merupakan zat gizi yang megandung nitrogen, sekitar $16 \%$ nitrogen terkandung dalam protein. Protein yang dikonsumsi secara berlebihan dapat menyebabkan gangguan kesehatan. Konsumsi tinggi protein akan menyebabkan ginjal dan hati bekerja lebih keras $^{14}$. Olahragawan yang terlalu banyak mengkonsumsi protein akan lebih sering kencing karena protein di dalam badan dicerna menjadi diurea akan kurang menyenangkan jika sering ke toilet sehingga dapat mengganggu latihan ${ }^{15}$. Oleh karena itu protein harus seimbang sehingga kebutuhan olahragawan tercukupi.

Berdasarkan hasil penelitian tidak terdapat hubungan asupan karbohidrat dengan kebugaran penelitian lain juga menyebutkan bahwa tidak terdapat hubungan tingkat konsumsi karbohidrat dengan kesegaran jasmani ${ }^{16}$. Karbohidrat merupakan sumber energi paling penting bagi manusia karena molekulnya menyediakan unsur karbon yang siap digunakan oleh sel. Glukosa merupakan sumber energi yang disukai oleh otot $^{17}$.

Tidak terdapat hubungan asupan lemak dengan kebugaran jasmani hasil tersebut sejalan dengan penelitian lain juga menyebutkan bahwa tidak terdapat hubungan tingkat konsumsi lemak dengan kesegaran jasmani. Lemak sebagai penghasil energi yang cukup besar namun olahragawan tidak boleh mengkonsumsi lemak secara berlebihan. Kebutuhan lemak yang dikonsumsi dalam sehari dianjurkan sebanyak $8 \%$ dari kebutuhan energi total yang berasal dari lemak jenuh kemudian 3-7\% lemak jenuh ganda. Lemak banyak terdapat dalam bahan makanan yang bersumber dari hewani misalnya daging berlemak, jeroan dan sebagainya.

Kebugaran jasmani merupakan kemampuan seseorang dalam melakukan tugasnya sehari tanpa mengalami kelelelahan ${ }^{18}$. Kebugaran jasmani memiliki dua komponen utama yaitu komponen kebugaran yang berkaitan dengan kesehatan adalah kekuatan otot, daya tahan aerobik dan fleksibilitas. Komponen kebugaran yang berkaitan dengan ketrampilan yaitu koordinasi, kelincahan, kecepatan gerak, power dan keseimbangan. Adapun faktor yang mempengaruhi tingkat kebugaran jasmani yaitu umur atau usia, jenis kelamin, makanan olahraga, kebiasaan hidup dan faktor lingkungan ${ }^{19}$.

Tes kebugaran jasmani merupakan tolak ukur untuk mengukur tingkat kesegaran jasmani yang terbentuk dari rangkaian tes kesegaran jasmani yang digolongkan menurut umur. Tes kesegaran jasmani dikategorikan menjadi baik sekali, baik, sedang, kurang dan kurang sekali ${ }^{20}$.

Pada tabel 3 menunjukkan bahwa status gizi kurus cenderung memiliki kebugaran jasmani sedang yaitu $46,4 \%$, status gizi normal cenderung memiliki kebugaran jasmani baik sebanyak $45,7 \%$, status gizi gemuk cenderung memiliki kebugaran jasmani kurang sebanyak $50 \%$ dan status gizi obesitas cenderung memiliki kebugaran jasmani baik sebanyak $100 \%$.

Berdasarkan hasil uji kolerasi pearson menunjukkan nilai $p=0,014$ ( $p>0,340)$ bahwa status gizi berhubungan dengan kebugaran jasmani. Hasil tersebut sejalan dengan penelitian lain bahwa status gizi berhubungan dengan kebugaran jasmani khususnya pada siswa kelas VII SMP Negeri 1 Kediri Tahun Ajaran 2012-2013 ${ }^{19}$. Penelitian lain juga menyebutkan bahwa ada hubungan antara status gizi dengan tingkat kebugaran jasmani siswi kelas $X$ SMK Surabaya Tahun Ajaran 2012-2013 ${ }^{21}$.

Penelitian ini memiliki kelemahan yaitu pada saat melaksanakan tes balke karena teori yang digunakan mempengaruhi hasil tes kebugaran jasmani baik atau rendah. Hal tersebut dapat diminimalisir dengan 
menggunakan alat bantu seperti tanda jarak lari per 100 meter yang dilakukan dalam waktu 15 menit.

\section{KESIMPULAN}

Konsumsi asupan energi dan karbohidrat laki dan perempuan belum memenuhi standar kebutuhan, konsumsi asupan protein laki dan perempuan sudah memenuhi, asupan lemak laki-laki sudah memenuhi sedangkan perempuan belum memenuhi. Status gizi olaharagawan sebagian besar normal, kebugaran jasmaninya baik. Asupan energi, protein, karbohidrat dan lemak tidak berhubungan karena semakin rendah asupan makan dan latihan tidak teratur maka kebugaran jasmaninya rendah. Status gizi berhubungan dengan kebugaran jasmani. Semakin baik status gizi (normal) maka kebugaran jasmaninya semakin baik. Diharapkan bagi pelatih untuk meningkatkan dan menguasai pembelajaran tes balke, diharapkan dapat melakukan pengukuran antropometri yaitu berat badan setiap satu bulan sekali dan diharapkan mahasiswa rajin mengikuti latihan taekwondo.

\section{ACKNOWLEDGEMENT}

Peneliti mengucapkan terima kasih kepada Ketua UKM taekwondo di Universitas Airlangga Surabaya memberikan izin untuk dijadikan tempat penelitian sehingga penelitian ini dapat terlaksana serta mahasiswa UKM Taekwondo di Universitas Airlangga Surabaya yang telah meluangkan waktu membantu penelitian ini.

\section{REFERENSI}

1. Fatmah, R. . Gizi Kebugaran dan Olahraga. (Lubuk Agung, 2011).

2. Chiodo, S. et al. Stress-related hormonal and psychological changes to official youth Taekwondo competitions. Scand. J. Med. Sci. Sports 21, 111-119 (2011).

3. Soekarti Sunita, M. Gizi Seimbang dalam Daur Kehidupan. (2013).

4. Departemen Kesehatan RI. Sistem Kesehatan Nasional. Dep. Kesehat. RI 569 (2009).
5. Adriani, M., Wirjatmadi, B. Peranan Gizi Dalam Siklus Kehidupan: (Prenadamedia Group, 2014).

6. Khasanah, N. Waspadai Beragam Penyakit Degeneratif Akibat Pola Makan. (Laksana, 2012).

7. Syafrizar., Welis, W. Gizi Olahraga. (Wineka Media, 2009).

8. Yayasan Institusi Danone Indonesia. . Pedoman Gizi Seimbang Untuk Anak Usia Sekolah Dasar. (PT Citra Kreasindo).

9. Kuntoro. Metode Sampling dan Penentuan Besar Sampel. (Pustaka Melati IKAPI, 2008).

10. Putra, Y. . Perbedaan Tes Balke, Tes Cooper, dan Tes Multistage Terhadap Daya Tahan Aerobik Atlet Bola Voli Yuso Sleman. (Universitas Negeri Yogyakarta, 2013).

11. Gibson, R. S. Principles of Nutritional Assessment. Oxford University Press 292 (2005).

12. Novitasari, D. A. \& Rahfiludin, M.Z., S. Tingkat Konsumsi Energi, Aktivitas Fisik Dan Kesegaran Jasmani Pada Posisi (Tosser Dan Smasher) Atlet Bola Voli. J. Kesehat. Masy. 4, 38-45 (2016).

13. Umasangaji, M. . Hubungan Antara Asupan Energi Protein, Status Gizi Dengan Kesegaran Jasmani Pada Anggota Klub Tenis Meja Satelit Dan Salero Star Kota Ternate. (Universitas Politeknik Kesehatan, 2012).

14. Almatsier, S. Prinsip dasar ilmu gizi. (Gramedia Pustaka Utama, 2002).

15. Departemen Kesehatan RI. Profil Kesehatan Indonesia. Departemen Kesehatan RI (2008). doi:10.1111/evo.12990

16. Hastuti, P. N. \& Zulaekah, S. Hubungan tingkat konsumsi karbohidrat, protein dan lemak dengan kesegaran jasmani anak sekolah dasar di SD N Kartasura I. J. Kesehat. 2, 49-60 (2008).

17. Mulyaningsih, F., Kriswanto E.S., Yudanto, J. . Pendidikan Jasmani Olahraga dan Kesehatan. (Pusta Kurikulum dan Pembukuan Kementrian Pendidikan Nasional, 2010).

18. Suharjana. Pendidikan Kebugaran Jasmani. (FIK UNY, 2008). 
19. Widiastuti. Tes dan Pengukuran OlahragaNo Title. (Rajawali Press, 2015).

20. Irianto, D. . Tes dan Pengukuran Olahraga. (CV Andi Offset, 2007).
21. Ridwanda, A., Nurhayati, F. Hubungan Antara Status Gizi Dengan Tingkat Kebugaran Jasmani Pada Siswi Smk Negeri 1 Surabaya Kelas X Tahun Ajaran 2012-2013. J. Pendidik. Olahraga dan Kesehat. 1, 291-295 (2013). 